great an opportunity of real service to the community and to the country as any of the professions. There are many thousands of companies in industry and commerce who want an educated intake but who are harassed by the deficit due to a shortage of teachers. Such difficulties could be solved, he suggests, by a system of senior part-time appointments or temporary secondments, or by alleviating the problem of the shortage of teachers itself. However, he directs attention to the fact that it cannot be claimed that we are deploying Britain's full resources so long as women play such a small part in our industrial, scientific, technological and high-management activities. Sir Hugh also touches on the increasing specialization which now occurs right through industry. These specializations are now acceptable, and the formal ladder of promotion and success must be by one or other specialization. The great task that confronts all who are training managers is to produce people who, while initially master of one or other specialization, can at the same time understand how the other parallel and complementary specializa. tions all build the one body, whether it is their own company or the industry of which their company is a unit. Only by such means will they be capable of becoming managers with wide responsibilities.

\section{Mental Health}

During 1959-60 the major concorn of the National Association for Mental Health has been with the promotion of World Mental Health Year in the United Kingdom and with preparations for the coming of the Mental Health Act. These are described in the fourteenth annual report (Pp. 55. London: National Association for Mental Health, 1960). Before the Mental Health Act received the Royal Assent on July 29, 1959, the Ministry of Health had issued circulars in anticipation of its coming. The most noticeable was that issued during January 1958, authorizing the informal admission of patients to mental deficiency hospitals. Following the passing of the Mental Health Act, the Minister of Health issued a direction to local authorities asking them to submit details of their proposals for community care. These are now being studied at the Ministry. Another development of considerable importance to the Association is the initiative of the Royal College of Nursing in petitioning the Privy Council for an alteration in its Charter to enable all registered nurses to become members of the College. If the petition is granted, mental nurses, male and female, may, for the first time, become members of the Royal College of Nursing. Information about the work of the Association can be obtained from Maurice Craig House, 39 Queen Anne Street, London, W.1.

\section{Polish Scientfiic Publications}

THE Quarterly Review of Publications, published since 1955, describes publications of the Polish Academy of Sciences and of such scientific societies as are supported by the Academy. For the convenience of readers interested in particular disciplines, the Review has appeared since 1958 in three series: Series $A$, Social Sciencos; Series $B$, Biological Sciences; and Series $C$, Pure and Technical Sciences. To give the reader a more complete picture of current Polish scientific literature, the editors have decided to include in the Review the more important scientific publications of institutions other than the Polish Academy of Sciences and the affiliated societies. Each entry published in the Review is supplemented by a brief summary. Titles are quoted in the language used by the author and, except in the case of Latin and Greek titles, an English translation is given. Copies of the Revieu can be obtained from the Distribution Centre, Warszawa, Palac Kultury, 1, Nauki.

\section{Peabody Museum of Yale University}

The annual report of the Peabody Museum of Yale University for 1960 is unusual in that it is the first to be issued by the Museum and is also the first by the present director, Mr. S. Dillon Ripley (Pp. 31. New Haven, Conn.: Peabody Museum of Natural History, Yale University, 1960). It also coincides with the re-activation of the Museum Trustees and the Advisory Committee. The report records the opening of the new wing on October 30,1959 , which event marked the culmination of nearly 15 years planning. The director rightly states that the health of a museum depends not only on the development of exhibits, or the active progress of school services, but also on the calibre of the research by the staff and those associated with it. An impressive list of publications is a measure of the research carried out by this Museum. It is intended that reports should include semi-popular articles on natural history subjects- the first one being on the wren.

\section{The Australian Museum}

THE first part (two stories) of the new six-storey wing of the Australian Museum was officially opened by the Premier of New South Wales, Mr. R. J. Heffron, on August 11. The completion of this first part is one of the outstanding events in the history of the Museum, for it is the first major building addition for half a century. The now work is faced with handsome sandstone and contains curatorial offices, laboratories and space for reserve collections. The contract for the erection of the other four floors has already been signed and these will enable further collections to be displayed and also provide for a public cafeteria on the roof.

\section{Impact of Lunik 2 on the Moon}

At about the time when Lunik 2 struck the Moon, 21h. 02m. 24s. U.T. on September 13, 1959, optical observers in several parts of Europe noted small disturbances on the Moon's surface. Their observations, none of which could be certainly linked with Lunik 2, were reviewed by G. Fielder (see Nature, $185,11 ; 1960)$. One group of observations, from Hungary, has now been described in more detail by L. Detre, in a publication entitled "Bericht über" Optische Beobachtungen Anlässlich der Landung der Sowjetischen Mondrakete Lunik II" (Mitteilungen der Sternwarte der Ungarischen Akademie der Wissenschaften. Nr. 45: Pp. 10. Budapest : Sternwarte der Ungarischen Akademie der Wissen. schaften, 1960). On the night of September 13, which was exceptionally clear in Hungary, an expanding dark spot was observed on the moon, near the crater Autolycus, by several astronomers at two independent observatories, Szabadsághegy and Baja, between the times $21 \mathrm{~h}$. 02m. 30s. U.T. and $21 \mathrm{~h}$. $07 \mathrm{~m}$., when it became too diffuse to observe. Traces of $a$ similar phenomenon were found on photographs taken at the same time at Uppsala, Sweden. The coordinates of the dark spot $(+0.03,+0.45)$ agreo well with those given for the impact point of Lunite 2 . 